\title{
Pengaruh Perebusan Daun Mangrove (Avicennia marina) dengan Air Abu Sekam terhadap Kecernaan Fraksi Serat (NDF, ADF, Selulosa, dan Hemiselulosa) Secara In-Vitro
}

\section{Effect of Boiling Mangrove (Avicennia marina) Leaves in Husk ash Water on In-Vitro Digestibility of Fiber Fraction (NDF, ADF, Cellulose, and Hemicellulose)}

\author{
G. Yanti ${ }^{1 *}$, N. Jamarun ${ }^{2}$, dan Elihasridas ${ }^{2}$ \\ ${ }^{1}$ Program Doktor, Fakultas Peternakan, Universitas Andalas, Padang - Indonesia \\ ${ }^{2}$ Fakultas Peternakan, Universitas Andalas, Padang - Indonesia \\ *Corresponding E-mail: gusriyanti594@gmail.com \\ (Diterima: 24 November 2020; Disetujui: 31 Maret 2021)
}

\begin{abstract}
ABSTRAK
Penelitian ini bertujuan melihat pengaruh intensitas waktu perebusan daun mangrove (Avicennia marina) terhadap nilai kecernaan fraksi serat (NDF, ADF, selulosa dan hemiselulosa) secara in-vitro. Analisis perhitungan penelitian dilakukan dengan menggunakan metode Rancangan Acak Kelompok (RAK). Penelitian ini dilakukan dengan membandingkan nilai kecernaan NDF, ADF, Selulosa, dan Hemiselulosa melalui pengukuran berdasarkan intensitas waktu perebusan daun mangrove menggunakan air abu sekam 15\% (w/v). Perlakuan intensitas waktu dengan rentang : selama 0 menit (P0), 5 menit (P1), 10 menit (P2), dan 15 menit (P3). Hasil penelitian membuktikan bahwa waktu perebusan daun mangrove menggunakan air abu sekam 15\% mempengaruhi sangat nyata $(\mathrm{P}<0,01)$ terhadap nilai kecernaan NDF, ADF, selulosa, dan hemiselulosa. Persentase nilai kecernaan in-vitro tertinggi didapat pada perlakuan P2 (10 menit perebusan) dengan nilai Kecernaan NDF (63,04\%), Kecernaan ADF (53,86\%), Kecernaan selulosa (80,99\%) dan nilai Kecernaan hemiselulosa $(81,44 \%)$. Kesimpulan hasil penelitian ini menjelaskan bahwa perebusan daun mangrove (Avicennia marina) rentang waktu 10 menit menjadi waktu yang optimum dalam menghasilkan kecernaan fraksi serat terbaik secara in-vitro.
\end{abstract}

Kata kunci: daun mangrove, perebusan, abu sekam, kecernaan invitro, fraksi serat

\begin{abstract}
This study aims to determine the effect of the time intensity of boiling mangrove leaves (Avicennia marina) on the digestibility value of fiber fractions (NDF, ADF, cellulose, and hemicellulose) in vitro. The analysis of the research calculations was carried out using a Completely Randomized Design. In this study, it was carried out by measuring the intensity of the boiling time of mangrove leaves using $15 \%(\mathrm{w} /$ v) husk ash water with ranges: for 0 minutes (P0), 5 minutes (P1), 10 minutes (P2), and 15 minutes (P3). The results showed that boiling mangrove leaves using $15 \%$ husk ash water had a very significant effect $(P<0.01)$ on the digestibility values of NDF, ADF, cellulose, and hemicellulose. The highest percentage of in-vitro digestibility values was obtained in P2 treatment (10 minutes of boiling) with NDF digestibility (63.04\%), ADF digestibility (53.86\%), cellulose digestibility (80.99\%), and hemicellulose digestibility values $(81,44 \%)$. The conclusions of this study explained that the boiling of mangrove leaves (Avicennia marina) within 10 minutes was the optimum time to produce the best fiber fraction digestibility in-vitro.
\end{abstract}

Keywords: mangrove leaves, boiling, husk ash, digestibility, fiber fractions 


\section{PENDAHULUAN}

Hijauan bersama konsentrat dimanfaatkan untuk bahan pakan utama ternak Ruminansia karena memiliki peranan prioritas dalam memenuhi kebutuhan pokok, produksi serta reproduksinya. Secara umum, hijauan untuk pakan yang digunakan oleh peternak lokal antara lain rumput lapangan, limbah hasil pertanian serta beberapa jenis rumput berkategori unggul dan berkualitas. Akan tetapi produksi rumput yang berkualitas di Indonesia masih rendah sehingga ketersediaannya masih terbatas. Hal tersebut dikarenakan petani atau peternak lebih memilih menanam tanaman pangan produktif semisal padi dan jenis palawija dibanding memproduksi rumput unggulan sebagai pakan ternak. Hal ini juga dilatarbelakangi dengan pesatnya pertumbuhan penduduk di Indonesia sehingga kebutuhan terhadap pangan juga mendesak dan terus bertambah.

Kondisi ini secara tidak langsung mengancam peternak karena ketersediaan pakan khususnya hijauan yang berkualitas menjadi terbatas. Untuk mengatasi persoalan tersebut peternak perlu melakukan upaya alternatif dalam penyediaan hijauan pakan dalam jumlah besar. Dilihat dari komposisi dan kandungannya, salah satu jenis tumbuhan yang dapat dijadikan sebagai hijauan alternatif untuk ternak ruminansia yakni kelompok mangrove atau bakau. Terlebihjumlah populasi mangrove di Indonesia melimpah, sehingga cukup potensial dimanfaatkan sebagai pakan alternatif menggantikan rumput. Salah satu mangrove yang dinilai prospektif dijadikan hijauan yakni jenis Avicennia marina atau bahasa Indonesianya Api-api.

Avicennia marina memiliki potensi sebagai hijauan, karena memiliki daun dan buah yang mengandung banyak senyawa makanan antara lain vitamin, lemak, kalori, asam amino, protein, serat, karbohidrat, dan mineral ( $\mathrm{Fe}, \mathrm{Mg}, \mathrm{Ca}, \mathrm{K}, \mathrm{Na})$. Wibowo et al. (2009) menyebutkan daun mangrove seperti Avicennia marina memiliki kadar protein sebesar $17,31 \%$. Tingginya kadar protein daun mangrove juga diikuti dengan tingginya kandungan tanin yang akan berpengaruh negatif pada tubuh ternak apabila dikonsumsi dengan intensitas banyak. Dalam penelitian Takarina dan Patria (2017) menjelaskan daun mangrove mengandung tanin sekitar $13,44 \%$ yang menjadikannya sebagai anti nutrisi dan berpengaruh negatif pada ternak apabila terlalu banyak dikonsumsi. Dilansir dari Fahey and Berger (1988), tanin berupa senyawa fenol yang memiliki gugus hidroksil dan dapat secara efektif mengikat secara silang molekul protein dan senyawa lain semisal karbohidrat jenis polisakarida, asam amino, asam lemak serta asam nukleat. Hal ini diperkuat Trisnadewi (2014) yang menyatakan saat kandungan tanin meningkat dalam ransum menyulitkan karbohidrat dan protein yang diikat oleh tanin terdegradasi oleh mikroba rumen yang menyebabkan aktivitas enzim menurun. Akibatnya, degradasi atau kecernaan bahan kering rumen secara invitro ikut menurun sehingga ketersediaan karbohidrat dan protein bagi mikroba juga semakin sedikit.

Dalam mengatasi persoalan tersebut diperlukan upaya mengurangi kandungan tanin pada daun mangrove. Salah satu alternatif mengurangi kadar tanin tersebut dengan perebusan menggunakan bahan aktif seperti senyawa organik. Dalam hal ini dapat menggunakan abu hasil pembakaran sekam padi yang dapat menjadi sumber kalium serta mengandung silikon dioksida. Penelitian Nirwani dan Endang (2017) menjelaskan bawah hasil perebusan buah mangrove menggunakan kadar abu sekam cukup efektif untuk menurunkan kadar tanin. Analisisnya perebusan buah dengan kadar abu 15\% akan lebih efektif dalam menurunkan kadar tanin dibandingkan dengan perebusan buah mangrove dengan kadar abu sekam 5\%. Dari perhitungan tersebut menjelaskan, abu sekam dapat menurunkan kandungan tanin dalam buah mangrove. Selain menurunkan kandungan tanin pada buah mangrove (Avicennia marina), penggunaan abu sekam juga dapat menurunkan kadar tanin pada 
daun mangrove karena dapat menghambat pembentukan oksidasi tanin dan mengikat tanin.

Hargeman (2002) memaparkan bahwa pemanasan dengan suhu $98^{\circ} \mathrm{C}-101^{\circ} \mathrm{C}$ dapat menguraikan tanin menjadi glukosa dan asam galat. Perebusan dilakukan bertujuan untuk melembutkan tekstur bahan karena dengan perebusan terjadi perenggangan struktur sel pada bahan. Suatu bahan yang telah direbus akan memiliki tekstur yang lebih lunak sehingga mudah diproses dalam pencernaan. Tujuan penelitian ini untuk melihat intensitas waktu perebusan daun mangrove (Avicennia marina) mempengaruhi hasil kecernaan fraksi serat antara lain NDF, ADF, selulosa, dan hemiselulosa secara in- vitro.

\section{METODE}

Pengambilan Sampel Daun mangrove (Avicennia marina) dilakukan di wilayah Nagari Ampang Pulai, Kabupaten Pesisir Selatan, Sumatera Barat. Dalam pengambilan sampel, daun mangrove diambil bagian atas (3-4 helai daun teratas) seperti cara memetik daun teh. Kemudian Bahan lain yang digunakan yakni air abu sekam, aquades, cairan rumen, larutan McDougalls sebagai buffer, bahan kimia untuk analisis in-vitro dan kecernaan fraksi serat, serta seperangkat alat yang digunakan untuk pengukuran degradasi zat makanan secara in-vitro.

Metode yang digunakan dalam penelitian ini yakni eksperimental, dengan analisis memakai metode Rancangan Acak Kelompok (RAK) melalui 4 perlakuan serta 5 kelompok, yang terdiri atas $\mathrm{P} 0=$ Tanpa Perebusan, P1 = Lama perebusan 5 menit, P2 $=$ lama perebusan 10 menit perebusan, dan P3 = lama perebusan 15 menit. Pada perlakuannya daun mangrove direbus di dalam larutan air yang mengandung kadar abu sekam 15\%, dengan lama waktu perebusan sesuai dengan perlakuan. Perlakuan perebusan dengan air abu sekam dengan konsentrasi kadar 15\% mengacu pada penelitian Endang dan Nirwani
(2017).

Kemudian daun mangrove yang telah direbus lalu dibilas dengan air mengalir secara berulang-ulang dan dikeringkan serta dihaluskan. Setelah itu dilakukan uji kandungan fraksi serat dengan metode Van Soest (1995), dan diukur kecernaan fraksi serat secara in-vitro menggunakan metode Tilley and Terri (1965).

\section{HASIL DAN PEMBAHASAN}

Dari hasil memperlihatkan perlakuan berpengaruh berbeda sangat nyata $(\mathrm{P}<0,01)$ terhadap kecernaan in-vitro NDF, ADF, selulosa dan hemiselulosa. Hasil tertinggi kecernaan in-vitro dari seluruh parameter yang diukur terdapat pada perlakuan P2 yaitu waktu perebusan selama 10 menit, sedangkan hasil terendah diddapat pada perlakuan $\mathrm{P} 3$ dengan intensitas waktu perebusan 15 menit. Melalui uji lanjut DMRT memperlihatkan terdapat pengaruh berbeda sangat nyata $(\mathrm{P}<0,01)$ antara kontrol (P0) dengan perlakuan waktu perebusan menggunakan air abu sekam kadar $15 \%$ dengan waktu 10 menit (P2) (Tabel 1). Hal ini menjelaskan bahwa perebusan daun mangrove menggunakan air abu sekam dapat meningkatkan kecernaan in-vitro NDF, ADF, selulosa dan hemiselulosa.

Peningkatan kecernaan ini terjadi akibat pengaruh waktu perebusan daun mangrove dengan air abu sekam yang mampu menurunkan kadar tanin hingga 10,27\%. Hargeman (2002) menyebutkan pemanasan dengan suhu $98^{\circ} \mathrm{C}-101^{\circ} \mathrm{C}$ dapat memecah tanin menjadi glukosa dan asam galat. Selain itu dengan menambahkan abu sekam sebanyak $15 \%$ dalam perebusan semakin memperkuat pemutusan ikatan tanin ataupun pollifenol lainnya dengan protein, karbohidrat, vitamin dan mineral. Pambayun (2000) menjelaskan abu sekam dapat menyerap cairan dalam sel, mengikat zat racun dan anti nutrisi. Tambahannya, penurunan kadar tanin aktif yang mengikat karbohidrat dan protein serta molekul lainnya berdampak juga 
Tabel 1. Rataan kecernaan in-vitro Neutral Detergent Fiber (NDF), Acid Detergent Fiber (ADF), kecernaan selulosa, dan hemiselulosa (\%)

\begin{tabular}{lcccc}
\hline Perlakuan & NDF & ADF & Selulosa & Hemiselulosa \\
\hline P0 & $56,45^{\mathrm{b}}$ & $45,45^{\mathrm{b}}$ & $70,37^{\mathrm{c}}$ & $77,35^{\mathrm{b}}$ \\
P1 & $57,23^{\mathrm{b}}$ & $45,45^{\mathrm{b}}$ & $72,80^{\mathrm{b}}$ & $76,93^{\mathrm{b}}$ \\
P2 & $63,04^{\mathrm{a}}$ & $53,86^{\mathrm{a}}$ & $80,99^{\mathrm{a}}$ & $81,44^{\mathrm{a}}$ \\
P3 & $49,74^{\mathrm{c}}$ & $36,29^{\mathrm{c}}$ & $68,31^{\mathrm{c}}$ & $68,09^{\mathrm{c}}$ \\
\hline SE & 1,31 & 1,31 & 0,75 & 1,12 \\
\hline
\end{tabular}

Keterangan: Perlakuan memberikan pengaruh berbeda sangat nyata $(\mathrm{P}>0,01), \mathrm{SE}=$ Standar Error

meningkatnnya kecernaan serat kasar (Tabel 2).

Pada Tanin terdapat senyawa fenol yang memiliki gugus hidroksil dan dapat efektif mengikat secara silang molekul protein dan senyawa lain semisal karbohidrat jenis polisakarida, asam amino, asam lemak serta asam nukleat. Abu sekam mengandung silika yang bersifat alkali. Perebusan dengan air abu sekam akan menginaktifkan gugus tanin fenolik aktif yang mengikat protein, karbohidrat dan molekul-molekul lainnya (Bensalem, 2005). Ikatan kuat antara tanin dan protein, karbohidrat serta zat lainnya akan berpengaruh terhadap kecernaan serat. Serat kasar adalah komponen penyusun karbohidrat yang terdiri atas polisakarida bersifat tidak larut seperti selulosa, hemiselulosa dan lignin. Penurunan kadar tanin aktif akan mengikat karbohidrat, sehingga karbohidrat dapat didegradasi dengan baik oleh mikroba rumen, dampaknya kecernaannya juga akan meningkat.

Peningkatan rataan degradasi NDF, ADF, selulosa dan hemiselulosa terjadi dalam daun mangrove dengan perebusan air abu sekam kadar 15\%. Kemudian pada perlakuan P2 (10 menit) didapatkan hasil kecernaan invitro NDF, ADF, selulosa dan hemiselulosa meningkat dibanding perlakuan P0 (Tabel 1). Hal ini dapatterjadi karena efek daripemanasan yang dapat menurunkan kadar tanin (Zhigang et al., 2008). Pada penelitian ini kandungan tannin menurun sampai $10,27 \%$. Selanjutnya pada perlakuan P3 (15 menit) didapatkan nilai kecernaan in-vitro NDF, ADF, selulosa dan hemiselulosa kembali menurun. Salah satu penyebab adanya penurunan nilai kecernaan karena adanya komponen serat berupa pati. Pada prosesnya saat pati mengalami pemanasan, granula pati mengembang dan terjadi gelatinisasi, kemudian saat pemanasan selama 10 menitkecernaan meningkat. Setelah melewati proses pemanasan granula tersebut kembali pada kondisi awal. Sedangkan pada pemanasan 15 menit terjadi karamelisasi atau proses pencoklatan gula. Hal ini dijelaskan Agustina et al. (2013) bahwa kandungan pati berikatan erat dengan kandungan serat, sehingga saat mengalami pemanasan secara terus menerus, serat pangan yang terkandung pada bahan melarut atau mengalami destruksi yang menyebabkan kadar pati (karbohidrat) menurun. Dengan demikian menurunnya kecernaan pada waktu 15 menit (P3) disebabkan karena rusaknya zat zat makanan tersebut seperti protein dan karbohidrat serta zat lainnya. Penelitian Nsa et al. (2011) menjelaskan bahwa perebusan pada waktu lebih dari 10 menit dapat menurunkan kadar protein dan kandungan zat lainnya pada biji tanaman dalam hal ini buah jarak. Ini dapat dijelaskan penurunan kandungan nutrisi akibat lama perebusan akan menyebabkan turunnya tingkat kecernaan senyawa makanan yang terkandung pada bahan pakan.

Peningkatan nilai rataan degradasi NDF, ADF, selulosa dan hemiselulosa terjadi pada daun mangrove yang direbus menggunakan air abu sekam $15 \%$ selama 10 menit. Nilai kecernaan in-vitro hemiselulosa adalah nilai 
Tabel 2. Rataan penurunan tannin daun mangrove yang direbus menggunakan air abu sekam

\begin{tabular}{cccccc}
\hline Perlakuan & P0 & P1 & P2 & P3 & SE \\
\hline Tanin $(\%)$ & $11,1^{\mathrm{c}}$ & $14,91 \mathrm{a}$ & $10,89 \mathrm{~b}$ & $10,27 \mathrm{~b}$ & 0,33 \\
\hline
\end{tabular}

Keterangan: Perlakuan memberikan pengaruh berbeda sangat nyata $(\mathrm{P}>0,01), \mathrm{SE}=\mathrm{Standar}$ Error

tertinggi diantara parameter lain yang diukur. Nilai rataan hemiselulosa yang didapat pada penelitian ini berkisar antara 68,09$81,44 \%$. Sedangkan nilai rataan selulosa, NDF dan ADF berturut-turut 68,31-80,99\%, $49,74-63,04 \%$ dan $36,29 \%-53,86 \%$ (Tabel 1). Dari nilai tersebut terlihat hemiselulosa merupakan senyawa yang dapat mudah dicerna (Zulkarnaini, 2009). Van Soest (1982) menyimpulkan bahwa senyawa hemiselulosa mudah dimanfaatkan oleh mikroba rumen. Bila mengacu perbandingan peranan mikroba, bakteri hemiselulolitik yang tidak mampu mendegradasi selulosa, sadangkan bakteri selulolitik mampu mendegradasi hemiselulosa. Hal ini yang menyebabkan nilai kecernaan in-vitro hemiselulosa lebih tinggi dibanding nilai selulosa.

Nilai rataan degradasi NDF berada di rentang 49,74-63,04\%. Hasil ini lebih tinggi bila dibandingkan dengan nilai rataan degradasi ADF yang hanya berkisar 36,29$53,86 \%$ (Tabel 1). Ini juga menjelaskan bahwa kecernaan in-vitro NDF lebih tinggi dibanding kecernaan in-vitro ADF. Hal ini terjadi karena NDF memiliki sifat yang lebih mudah dicerna di dalam rumen. Van Soest (1982) mengatakan rata-rata daya cerna NDF lebih tinggi bila dibandingkan dengan daya cerna ADF, karena NDF memiliki sebagian fraksi yang mudah larut yakni hemiselulosa. Phillips et al. (2011) menyebutkan bahwa komponen penyusun ADF memiliki ikatan kuat dengan senyawa lignin menyebabkan komponen ADF lebih sulit didegradasi oleh mikroba rumen. Alasan Kandungan serat sulit dicerna karena tingginya kandungan lignin pada bahan tersebut sehingga nilai kecernaan juga rendah (Nsa et al., 2004).

\section{KESIMPULAN}

Hasil penelitian disimpulkan intensitas waktu perebusan daun Mangrove (Avicennia marina) menggunakan air abu sekam mempengaruhi rataan kecernaan invitro fraksi serat (NDF, ADF, selulosa, dan hemiselulosa). Sedangkan pada intensitas waktu perebusan terbaik adalah 10 menit dengan nilai rataan kecernaan in-vitro NDF (63,04\%), ADF (53,86\%), selulosa $(80,99 \%)$, dan hemiselulosa $(81,44 \%)$.

\section{UCAPAN TERIMA KASIH}

Ucapan terima kasih kepada Kementerian Riset dan Teknologi BRIN Memberikan dukungan khususnya pembiayaan penelitian ini melalui jalur pendanaan Penelitian Thesis Magister Tahun 2020 .

\section{DAFTAR PUSTAKA}

Agustina, N., Sri W., Warji, dan Tamrin. 2013. Pengaruh Suhu Perendaman Terhadap Koefisien Difusi dan Sifat Fisik Kacang Merah. Jurnal Teknik Pertanian Lampung. 2(1): 35-42.

Bensalem., Helmi,. Abidi., Sourour., Makkar., Harinder., Nefzaoui, and Ali. 2005. Wood ash treatment, a cost-effective way to deactivate tannins in Acacia cyanophylla Lindl. foliage and to improve digestion by Barbarine sheep. Fuel and Energy Abstracts. 122: 93108.

Fahey, G. C., and L. L. Berger. 1988. Carbohydrate nutrion of ruminants. In: D. C Chruch (Ed). Digestive Phisiology and Nutrition of Ruminants. 
The Ruminant Animal. Prentice Hall Eglewood Cliifs, New Jersey.

Hagerman, A. E. 2002. Tanin Chemistry. Handbook. Departemen Chemistry and Biochemistry. Miami Univ. Oxford.

Nirwani, S. dan Endang, S. 2017. Analisi Kadar Tanin Dalam Buah Mangrove Avicennia marina Dengan Perebusan dan Lama Perendeman Air yang Berbeda. Jurnal Kelautan Tropis. 20(2): 90-95.

Nsa, E. E., Ukachukwu, S. N., Isika, M. A., and Ozung, P. O. 2011. Effect of boiling and soaking durations on the proximate composition, ricin and mineral contents of undecorticated castor oil seeds (Ricinus communis). International Journal of Plant, Animal and Environment Sciences. 1(3): 244252.

Pambayun, R. 2000. Hydro Cyanic Acid and Organoleptic Test on Gadung Instant Rice from Various Methods of Detcsification. Seminar Nasional Industri Pangan. CO-13: 97-107.

Phillips, W., Horn, G. and Cole, N. 2011. The Relevancy of Forage Quality to Beef Production. Crop Science. 51.

Stell, R.G.D. dan J.H. Torrie. 1991. Prinsip dan Prosedur Statistik Suatu Pendekatan Biometrik. Gramedia. Jakarta.

Takarina, N. D. and Patria, M. P. 2017. Content of polyphenol compound in mangrove and macroalga extracts. International Symposium on Current Progress in Mathematics and Sciences 2016 (ISCPMS 2016).

Trisnadewi, A. A. S., Cakra, I. G. L. O., Wirawan, I. W., Mudita, I. M. dan Sumardani, N. L. G. 2014. Subtitusi Gamal (Glirisidia sepium) dengan Kaliandra (Calliandra calothyrsus) pada Ransum Terhadap Kecernaan Invitro. Pastura. 3(2): 106-109.

Van Soest, P. J. 1982. Nutritional Ecology of The Ruminant. Comstock Publishing Associates a Division of Cornell University Press, Ithaca and London.

Wibowo, C., Kusuma, C., Suryani, A., Hartati, Y. dan Oktadiyani, P. 2009. Pemanfaatan Pohon Mangrove Api-api (Avicennia sp.) sebagai Bahan Pangan dan Obat. IPB. Bogor. 160-165.

Zhigang, X., Moucheng, W., Dechao, S., and Rui1, X. 2008. Analysis on the effect of extrusion on tannin content in rapeseed meal. Transactions of the Chinese Society for Agricultural Machinery, 7: $1-5$.

Zulkarnaini. 2009. Pengaruh Suplementasi Mineral Fosfor dan Sulfur Pada Jerami Padi Amoniasi Terhadap Kecernaan NDF, ADF, Selulosa dan Hemiselulosa. Jurnal Ilmiah Tambuhan, III(3): 474477. 